Article

\title{
Faith-Based Organisations as Welfare Providers in Brazil: The Conflict over Gender in Cases of Domestic Violence
}

\author{
Kim Beecheno \\ Brazil Institute, King's College London, London, WC2R 2LS, UK; E-Mail: kim.beecheno@kcl.ac.uk
}

Submitted: 16 January 2019 | Accepted: 6 May 2019 | Published: 24 June 2019

\begin{abstract}
What does the growth of faith-based organisations (FBOs) in social welfare mean for women's rights and gender equality, especially within advocacy services for women experiencing domestic violence? Through empirical research within a Catholic-based organisation providing welfare services to abused women in São Paulo, Brazil, this article argues that FBOs can negatively impact the provision of women's rights when conservative and patriarchal views towards gender and women's roles in society are maintained. A heavily matrifocal perspective, where women's identity and subjectivity are mediated through their normative roles as wives, mothers and carers of the family, appears to offer little possibility of change for abused women, who are encouraged to forgive violent husbands and question their own behaviour. Mediation between couples is promoted, undermining women's rights upheld through Brazil's domestic violence law (Lei Maria da Penha no 11.340). Furthermore, the focus of family preservation, supported by a patriarchal state, means that violence against women (VAW) appears to be subordinated to a focus on family violence and violence against children. In this case, faith-based involvement in social welfare rejects the feminist analysis of VAW as a gender-based problem, viewing it as a personal issue rather than a collective or political issue, making women responsible for the violence in their lives.
\end{abstract}

\section{Keywords}

Brazil; Catholic church; domestic violence; faith-based organisations; gender; religion; violence; welfare; women; women's rights

\section{Issue}

This article is part of the issue "Exhausted Women-Exhausted Welfare: Understanding Religion, Gender and Welfare in Social Inclusion", edited by Martha Middlemiss Lé Mon (Uppsala University, Sweden).

(C) 2019 by the author; licensee Cogitatio (Lisbon, Portugal). This article is licensed under a Creative Commons Attribution 4.0 International License (CC BY).

\section{Introduction}

This article aims to demonstrate that controversy over gender roles and relations and differing views over the nature of women's roles in Brazilian society-linked to gender-traditional conservative Christianity on the one hand and feminist analyses of womanhood on the other-is played out within welfare services offering women help for domestic violence. Women's rights, female subjectivity and the ways in which women understand and negotiate violence are shaped through welfare provision, making these services highly political. In Brazil, the growth of faith-based organisations (FBOs) is consistent with a world-wide trend in which religious organisations play an increasing role in welfare, linked to neo-liberalism and austerity measures (Hjelm, 2015), and there is a growing body of literature examining the role of FBOs in providing state services (e.g., see Bäckström, Davie, Edgardh, \& Petterson, 2010; Biebricher, 2011; Ghatak \& Abel, 2013; Mead, 2005; Sager, 2010). However, few studies have taken a gendered perspective of FBOs (for exceptions see Bäckström et al., 2010; $\emptyset$ steb $\emptyset$, Haukanes, \& Blystad, 2013). Studies relating to Brazil have so far have focused on issues such as the social justice work of the progressive Catholic Church and its ecclesiastical base communities, prominent in the 1970-1990s (see Drogus, 1997; Drogus \& Stewart-Gambino, 2005; Mariz, 1992). Research has also addressed the role of FBOs and their work on HIV and AIDS, which has implications around concepts of gender and sexuality (e.g., see 
Parker, 2009). However, there are currently no studies which have taken an explicitly gendered perspective on the role of FBOs as welfare providers in Brazil, and none within the context of violence against women (VAW), highlighting the need for the current research.

According to Beckford (2011), discussions of religious organisations as social welfare providers underscore the way in which 'faith' has become a political resource and how governments have come to see "religion as expedient" (Beckford, 2011, p. 59). This concept refers to the policies and practices that acknowledge the potential of drawing on religious resources to solve problems (Beckford, 2011, p. 59). Hjelm (2015) has called for a critical approach to religion as expedient, pointing out what he called "the little-examined, unexpected consequences of these increased state-religion partnerships" (Hjelm, 2015, p. 9). For example, some feminist researchers such as Sheila Jeffreys (2011) argue that religions should not be included in government consultations or given contracts for the delivery of public services because "religions are usually discriminatory with respect to gender and equality" (Jeffreys, 2011, p. 364). This is because FBOs that partner with the state are supposed to support state values, aid in community integration and not infringe the rights of citizens. But in their study of Norwegian FBOs, $\varnothing$ steb $\varnothing$ et al. (2013) found clear tensions between faith-based service providers and women's empowerment programmes. The FBOs in question felt pressured to comply with state policies to continue receiving aid, highlighting the strains between a state focus on gender equality and perceptions of men and women's roles in conservative, gender-traditional religions. However, Aune and Nyhagen (2015) argue that a universal rejection of religion within social care generalises all religions and does not take into account historical, political and socio-economic contexts. Neither does it consider religious women's groups working to change gender relations from within their religion; or the ways in which women in gender-conservative religions find ways to circumvent patriarchal gender relations.

In Brazil, research has pointed to the important role of religious organisations in the construction of civil society (Giumbelli, 2008; Montero, 2012). This is linked to the country's vibrant 'third sector', heavily dominated by FBOs, which have been involved in the country's economic and social progress and have seen millions of Brazilians lifted out of poverty and social inequalities reduced (Mourier, 2013). FBOs are common because the Catholic church has a long history of providing social welfare and more recently, the growth of conservative evangelical Protestant groups has added to the large number of religious institutions concerned with social care. In the state of São Paulo, where the research for this article was conducted, the growth of religious entities contracted to provide public services has risen dramatically over the last few years and this looks set to continue across the country due to the state being overwhelmed or even absent in many vulnerable areas (Mourier, 2013).
However, in the case of VAW, the controversy lies in the fact that secular and religious approaches tend to differ in the ways that gender and the family are perceived, and some feminists consider religious approaches to VAW major challenges to the global rights-based approach (e.g., Merry, 2001; Orozco, 2009). Moreover, in Brazil, controversy over gender roles, relations and gendered identities have caused great polemic and feminists have decried a turn to religious fundamentalism which they say impinges on women's rights (Orozco, 2009). This is linked to the growth of conservative evangelical Protestants (mainly Pentecostals) in positions of power in government, who are seeking to limit or overturn certain gains in women's rights, working alongside the historically strong Catholic and Family lobbies. For example, the government is currently considering bills to reduce women's access to the morning after pill and tighten Brazil's strict abortion laws to make it illegal under any circumstances, including in cases of rape or threat to a woman's life, the current caveats under which abortion is allowed. The role of FBOs offering support for those experiencing VAW therefore creates intense debate over religious beliefs, constructions of gender, and the ways to best address VAW. This begs the question: what does the growth of FBOs in social welfare mean for women's rights and gender equality, especially when looked at through the prism of VAW?

\section{Violence Against Women in Brazil}

Since democratisation in the 1980s, the feminist movement has highlighted the issue of VAW, leading to important legal and policy changes in order to address the problem. The state now officially recognises VAW as a form of gender-based violence which results from power inequalities based on gender roles. VAW includes violence perpetrated or condoned by the state in any situation, within spousal or non-spousal relations and violence committed at home, work, within institutions or in public (United Nations [UN], 1993). However, research shows that women are at greater risk of being physically or sexually abused by an intimate partner than by any other perpetrator (Garcia-Moreno, Jansen, Ellsberg, Heise, \& Watts, 2006; RHR \& WHO, 2013). Intimate partner violence (IPV) falls within the categories of what is also known as family violence, wife battering and domestic violence. However, it should be noted that some feminist researchers contest the terms 'domestic' and 'family' violence which are widely used in literature, the media and policy documents because these include other forms of family-based violence, e.g., against children or elderly, and multiple possible perpetrators-siblings, extended family members, parents. Feminists argue that these terms deny the gender political and structural aspect of IPV and perpetuate the idea of VAW as a private affair (Boesten, 2014; Scheper-Hughes, 1993).

Statistics suggest that Brazil has very high levels of VAW, although due to problems including a lack of re- 
porting and discrepancies in the way forms of violence are recorded by local authorities, the data are likely to reveal far lower levels of violence than exist. For example, the Brazilian Forum for Public Security (Fórum Brasileiro de Segurança Pública) found that 47,643 rapes were reported to the police in 2014, which represents 1 rape every 11 minutes (Cerqueira, Coelho, \& Ferreira, 2017). However, Brazil's data collection agency, Instituto de Pesquisa Econômica Aplicada (IPEA), believes that as little as $10 \%$ of rape cases are reported to the police, due to fear of reprisal and humiliation and the taboo around the issue (Cerqueira $\&$ Coelho, 2014). In addition, a government report found that 1 in 5 women were victims of IPV (Secretaria de Transparência \& DataSenado, 2013) although this is likely to be too low considering a WHO report which found that IPV affects at least 1 in 3 women around the world (RHR \& WHO, 2013). Lethal VAW has also risen dramatically since democratisation in the 1980s and Brazil currently ranks fifth most dangerous country in the world for women (Waiselfisz, 2015). The results are statistics of an estimated 5.82 deaths per 100,000 women, the equivalent of 5,664 deaths per year or approximately 15 deaths per day (Garcia, Freitas, Marques da Silva, \& Höfelmann, 2013).

As $60-70 \%$ of female homicides are committed by men close to the victims, such acts of violence can be understood as an extreme manifestation of gender discrimination, used as a lethal weapon through which to maintain female subordination (Sagot, 2013, p. 2). Furthermore, although violence is known to affect all women across all levels of Brazilian society, regardless of race, age, status and education, in Brazil lethal VAW tends to happen more frequently to women of child-bearing age, with low levels of schooling, and predominantly of black or mixed race (Waiselfisz, 2015). In the case of Latin America, Sagot $(2013$, p. 1) argues that femicidethe killing of women based on their gender-is a form of "necropolitics", a system of stratification in which certain bodies-especially low-income, female and darkerskinned bodies-are vulnerable to marginalization, objectification and even death.

In Brazil, feminists blame the high levels of VAW on a patriarchal culture in which violence has been normalised since colonisation by the Portuguese from the 1500 s onwards. They argue that male VAW has historically been excused, legitimised, or gone unpunished and that gendered, racialized and class-based inequalities have been institutionalised by successive governments and influential institutions-including religious organisations-which have sought to maintain patriarchal control over women and their bodies (e.g., Marcílio, 1993; Myscofski, 2013). This is because colonial Brazilian society was shaped by the Portuguese Imperial government and Luso-Catholic ecclesiastical institutions. The Roman Catholic Church was the dominant cultural institution of the Portuguese empire, creating a framework within which men and women were given certain social and gendered expectations of their roles in society
(Myscofski, 2013). This varied not just according to gender, but also according to race, ethnicity and class. Indigenous communities were exploited, and Africans were brought to the country as slaves. Liberalism and independence in the 19th century brought legal reform and certain levels of secularisation which decreased the Catholic Church's power and increased state power (Dore, 2000). However, the adoption of the Napoleonic Code in postcolonial society maintained patriarchal authority in both the domestic and public spheres, limiting women's rights (Dore, 2000). The breakdown of public/private distinctions and challenges to traditional gender roles inadvertently occurred in the 20th century as a result of industrial development and economic policies developed by military dictatorships, which pushed vast numbers of women into the workforce (Dore, 2000).

During the 1960s, the historical allegiance between the Catholic Church and the military broke down following the Catholic Church's reorientation towards the doctrine of Liberation Theology (Htun, 2003). This included greater emphasis on lay participation and actions to benefit the poorest. The Catholic Church formally opposed the government and served as a hub for networks of social movements struggling to bring an end to authoritarian rule (Htun, 2003). The 1960s to 1980 s therefore represented a time of important social movement growth which made a lasting contribution to the strengthening of democracy and civil society (Htun, 2003). According to Drogus and StewartGambino (2005), an important by-product was the personal empowerment of poor women, which allowed for increased political awareness and a strengthened sense of citizenship. Church-based popular groups advocated for the poor in national politics, and women's movements grew, particularly in the form of Mothers' Clubs (Clubes de Mães), demanding crèches, improved sanitary conditions, running water and access to universal healthcare (Drogus, 1997; Drogus \& Stewart-Gambino, 2005). However, while Liberation Theology allowed women to carve out greater roles in the public sphere through mobilisation and demands on the state for social change, there were also attempts by the Church to squash rising gender consciousness (Drogus, 1997). This is because mobilisation for women's practical needs was promoted in support of family and neighbourhood issues, which were linked to the belief in women's unique abilitiesspringing from their maternity-to perceive and rectify certain kinds of problems in these spheres. Mobilisation beyond this, into women's political and strategic aims, was discouraged by the Church and hence the constraints inherent in women's culturally and religiously defined gender roles ultimately limited mobilisation and change (Drogus, 1997).

Nevertheless, feminist mobilisation grew and shone a light on the vast problem of VAW, linked to the simultaneous international focus on women's rights and women's health. In 1984, Brazil ratified the UN's Convention on the Elimination of all Forms of Discrimina- 
tion against Women (CEDAW), obliging states to eliminate all legal restrictions on women's full and equal participation in the economy and society (Htun, 2003). Further legal changes and improvement to advocacy services have occurred. For example, criticism of the way regular police stations and police officers responded to denunciations of violence led to the introduction of Women's Police Departments (WPDs) in 1985, staffed entirely by women (for a gendered discussion on WPDs see Hautzinger, 2007). The state also created the Women's Defence and Community Centre (Centro de Defesa e Convivência da Mulher), henceforward referred to as CDCMs. Brazil set up its first CDCM in 1990, and there are now approximately 220 across the country, although anti-violence campaigners suggest this is nowhere near enough (Instituto Patricia Galvão, 2017). It is these CDCMs which are under study in this research.

In 2006, Brazilian Congress passed the historic Maria da Penha law (no 11.340) making domestic violence a crime for the first time and giving protection to victims of any sex, including same-sex couples (Instituto Patricia Galvão, 2017). The law defines domestic violence and family VAW broadly as "any action or omission based on gender that causes a woman's death, injury, physical, sexual or psychological suffering and moral or patrimonial damage", and it affirms that the domestic VAW constitutes a form of violation of human rights (Instituto Patricia Galvão, 2017, p. 4). Whereas hearings for domestic violence had previously taken place in small claims courts often resulting in the payment of a fine, perpetrators now face arrest and imprisonment for up to three years (ibid). Furthermore, in 2015, the femicide law (Lei do Feminicídio, no 13.104), came into effect, giving harsher sentences for lethal gender-based VAW. However, while the Maria da Penha law was seen as a victory by feminist organisations because it toughened up penalties, it has been criticised for relying too heavily on criminalisation and not developing alternative, preventative programming for less extreme cases (Hautzinger, 2007; Instituto Patricia Galvão, 2017). Also, research suggests that the Maria da Penha Law has had virtually no impact on the reduction of violent female deaths (Garcia et al., 2013). This means that the law has not been an effective deterrent to men, who continue to practice gender-based violence and even kill their partners and ex-partners with apparently relative impunity. The lack of real change, despite visible moves to address male violence, points to deep structural and gender-based inequality within both society and the institutions tasked with solving the problems of VAW.

\section{Research Methodology}

For this research, I conducted studies within 2 statefunded CDCMs incorporated into the welfare system, offering help to female victims of violence. Both centres originally started out as non-governmental organisations (NGOs), one an ostensibly 'secular' organisation, set up by a feminist NGO to address VAW in the eastern periphery (zona leste) of São Paulo. The other one was set up by the local Liberation-theology-influenced Catholic Church in the Southern periphery (zona sul) of the city and as such is an FBO. According to the Brazilian researcher Evelina Dagnino, the government outsources certain welfare services to third party providers, such as NGOs and civil society organisations, including FBOs, because the state deems them to be "reliable interlocutors" (Dagnino, 2005 , p. 20). Therefore, rather than create CDCMs from scratch, the state awards contracts to organisations active in the field of VAW. State funding turns these organisations into CDCMs. Funding is conditional on the centre adhering to state policies and practices concerning VAW and allows the service providers to hire professionally trained psychologists, social workers and legal experts. The technical standards developed for CDCMs mean that they must all offer a 'tripod' of help, including psychological and emotional support through individual and group therapy, help accessing welfare services through support from social workers, and legal advice from a lawyer based on their rights under the Maria da Penha law. The centres also run classes for women's wellbeing and confidence, such as exercise and dance classes, and income generation, e.g., handicrafts classes. However, CDCMs are held accountable for their use of state funding and must send monthly reports to their local council detailing their spending budgets. The centres are also limited to helping a maximum of 100 women per month, including new and ongoing service users. As many service users need support over a long period of time, the limit means that some women have to be turned away or wait a long time before receiving help. Furthermore, CDCMs complain that government funding is very low, making it hard to attract certain professionals, e.g., legal experts.

The study took place over seven months and included participant observation and in-depth interviews. I focused on the discourses about gender, religion and violence that are represented in institutional documents produced by the centres, on discourses emerging from events at the centres, and on discourses that professionals/leaders and service users engage in, during in-depth interviews. I examined the ways in which religion, gender and violence were articulated and negotiated by both centre staff and service users in the centres, and the solutions offered for dealing with violence. I observed 12 group therapy sessions, conducted 12 in-depth interviews with service users (i.e., women experiencing violence) and I conducted 13 interviews with professional staff in the centres. The professional staff included 5 social workers, 3 psychologists, 2 managers, 2 administrative staff and 1 lawyer. I also conducted analysis of documents obtained from the centres in the form of leaflets, memos, government documentation and flyers. For triangulation purposes, I spoke to numerous people at meetings, events, in private and in public about VAW ( $n=180$ ) building up a picture of different facets of the issues pertaining to VAW in Brazil. 
Ethics approval was sought and obtained from the university institution. Interviews were conducted in Portuguese, recorded and transcribed, with consent from the interviewees. Data recorded during participant observation was taken down in note-form and later written up more extensively. The data was analysed through coding and grouping together information under themes such as 'gender', 'religion', 'violence'. The data for this article comes mainly from analysis of the Catholic-based CDCM, which has been renamed the Family Alliance in order to protect identities. For the same reason, first name pseudonyms are used in the article.

\subsection{The Family Alliance}

Located in the zona sul, one of the poorest neighbourhoods of São Paulo, the area has high rates of unemployment, low levels of schooling, precariousness of housing including many favelas (illegal housing settlements), and high levels of violence. At least $20 \%$ of heads of households have no income whatever, residents generally have an average of 6 years of schooling and around $10 \%$ of people are completely illiterate (Vilhena, 2011). According to data obtained from the centre, the Family Alliance is the only centre for women in an area of approximately 600,000 people. The service users are typically aged 26 to 55 and have between 1 and 4 children. Most are economically dependent on their partners as they are the main carers for the family and many of the families include people who are addicted to alcohol or drugs, problems strongly prevalent in these low-income communities. In approximately $60 \%$ of cases, the husband or partner is responsible for the violence, while in other cases it is family members including parents, older children, in-laws, cousins, aunts and uncles. The staff found emotional and psychological violence to be the most prevalent form of violence, followed by physical violence, then material abandon and approximately $10 \%$ of women had received death threats.

\subsubsection{Religion at the Family Alliance}

Due to its inclusion within the ostensibly secular welfare system, the centre is not supposed to offer services using an overt faith-based perspective, and the staff described the centre as ecumenical. "We might read the Gospel, or recite a prayer, but we don't hold services", said Lisa, the centre manager, keen to emphasise that Catholicism was not preached in the centre. However, many members of staff were motivated by Catholic Liberation theology which promotes activism and social work. Moreover, within the centre itself, religious symbols abounded, from crosses above doors to small figures of the Virgin Mary in most rooms. Brazil is a country where less than $10 \%$ of the population identify as atheist, where the majority are Catholic (66\%) and where there is a growing evangelical Protestantespecially Pentecostal-population (22\%), particularly in low-income, urban areas such as the zona sul (Vilhena, 2011). This is perhaps because Pentecostal conversion is sometimes viewed as a strategy for dealing with poverty, as well as physical and social insecurity (e.g., Goldstein, 2003; Rostas \& Droogers, 1993; Stoll, 1990). In addition, patriarchal, racial and faith-based prejudice make admitting to following Afro-Spiritist religions such as Umbanda or Candomblé heavily frowned upon. It is therefore very likely that the religious symbolism so strongly present in all the rooms was nothing out of the ordinary for the women who used the centre's services. Furthermore, the country-wide statistics were reflected in the religious background of the service users, most of whom were Catholic (approximately 65\%), a sizeable number of whom were Pentecostal (approximately 30\%) and none of the women identified as either atheist or Spiritist. According to the staff, service users would identify as non-practising Catholics rather than atheist or agnostic, which underscores the symbolic strength of faith in Brazil, where identifying as a non-believer is still considered shocking.

There is a largely negative view of religion in the literature on organisations combating domestic violence, because religion is often presented as a mechanism through which VAW is supported and legitimised (Bradley, 2010; Dobash \& Dobash, 1980; Lewy \& Dull, 2005; Merry, 2001; Nason-Clark, 1997; Plesset, 2006; Vilhena, 2011). According to Nason-Clark (1997) women with strong religious belief may be more likely to stay in an abusive relationship for longer and work harder at saving the marriage than secular women because they believe that a marriage vow made in front of God cannot be undone. The message that the family is sacred and that women are held to be the caretakers of the family, responsible for its well-being, can make women more likely to believe that the violence is God's will or their own fault (Nason-Clark, 1997). Vilhena (2011) argues that because conservative Pentecostal groups tend to interpret the Bible in a very literal manner and focus heavily on the importance of female submission to a male partner (at least in Brazil), this can leave women highly vulnerable to IPV. Therefore, women of faith from patriarchal and conservative, gender-traditional religions who experience IPV may struggle more than their 'secular' counterparts to deal with the violence as their understanding of their gendered roles as mothers and subservient housewives makes it difficult to identify and act upon the situation of abuse in which they find themselves (Nason-Clark, 1997). On the other hand, research has also highlighted that some pious women use religious involvement to help heal domestic distress (Chong, 2008; Haaken, Fussell, \& Mankowksi, 2007; Nason-Clark, 1997). For example, studying conservative evangelical Protestants in the US, Haaken et al. (2007) found that faith-based discourse on domestic violence was being addressed through the integration of 'biblical feminism' and traditional interpretations of scripture. This demonstrates female agency and shows that while traditional, patriarchal gender patterns 
remain unchanged, women of faith can find ways to address the violence they experience within the parameters of their religion.

Yet, at the Family Alliance, staff told me that religion was not of importance in the centre. They said that they did not use a religious perspective in counselling sessions and they felt that for most of the women they dealt with, religion did not play an important role in their lives. Monica, the psychologist, said that most of the women were not even particularly religious and that it was something the women rarely talked about during counselling: "most of them [abused women] don't bring religion into it". This is interesting because at the so-called 'secular' centre where a feminist perspective was used to address violence, staff identified religious belief as a reason many abused women gave for not wanting to separate from their husbands, despite the violence they experienced. At the Family Alliance, Lisa, the centre manager, explained that on the rare occasions when religion did emerge as an issue, it was usually in connection to women from conservative Pentecostal faiths, and the staff addressed this from a theological perspective:

We have to talk to these women [Pentecostals] about God and Jesus. Who is Jesus Christ? What does he want from us? We have to discuss the fact that God is not a god who cures all ills, and He isn't a god who punishes either. He is the God of life and abundance; it is sometimes very hard to make them see that they can break with this [domestic] violence. (Lisa, centre manager, April 20, 2014; personal communication)

The staff clearly attempted to address the issue of faith and IPV by addressing differences in Catholic and Pentecostal theology, highlighting the importance of the Catholic (and specifically Liberationist) perspective at the centre. The faith-based perspective also meant that religious tradition was not identified as a factor impacting on the situation of IPV, unless the theology differed from Catholicism.

\subsubsection{Gender, Violence and Women's Rights}

Despite not using an overt religious perspective within the centre, through interviews as well as listening to the conversations and advice that was given to the abused women at the centre, I noted a strong focus on the family and a rejection of the feminist analysis of violence as a form of gender-based violence. Furthermore, there was clear support among staff for mediation between the abuser and the battered woman and there was also a strong focus on a woman's role in domestic violence. Monica explained:

I would never call myself a feminist.... don't like it because you know here [the Family Alliance], the focus is on the woman, but if I can focus on the family then that's what I do. The feminist focus is just to focus on the woman and she's not everything. You have to think, is domestic violence only men's fault? Feminism just focuses on women and I don't agree with that. Of course, we listen to the woman, but our focus is really the family, as well as listening to the children and sometimes bringing the couple in together for mediation. (Monica, Psychologist, March 5, 2015; personal communication)

The staff questioned women's behaviour within the relationship, refuting the feminist belief that women are (almost) always the victims of IPV due to unequal gender relations and the patriarchal nature of society. The family focus at the centre means that women's sense of identity and subjectivity is mediated through their gendered, normative role as wife, mother and carer for the family. This suggests that while a religious perspective is not directly used to address VAW, the Catholic background of the centre influences a traditional and relatively conservative view towards gender roles and relations. Moreover, this conservative view of gender influences the way in which violence is understood and the solutions proposed for addressing violence. This could be seen in the use of mediation as a strategy to reduce violence and improve domestic relations. For example, a service user named Sandra was offered mediation when she told the staff that she wanted to separate from her husband. Sandra explained to me that domestic relations had improved for a while with the mediation. However, as the cycle of drinking and violence had begun again, she had returned to the centre. Sandra felt helpless and overwhelmed, and regularly broke down in tears. Mediation appeared to only be a temporary solution which offered little transformation, allowing cycles of abuse to begin again.

Offering mediation in a CDCM is unusual, because men are usually banned from entering the centres for women's safety. However, in 2009, the staff at the Family Alliance decided that men could be brought in for mediation if the abused women agreed. The timing of this, two to three years after the implementation of the Maria da Penha law in late 2006, suggests that the law caused some changes that the staff felt moved to address. Before the law came into effect, cases of domestic violence were usually held in small claims courts where men were required to apologise and give the woman a gift, usually in the form of a cesta básica, a gift box of food (Macaulay, 2005). Even before cases got to court, the police were notorious for trivialising domestic violence and encouraging the woman to withdraw the complaint (ibid). The Maria da Penha law was therefore designed to stop the mediation that had been occurring in police stations and small claims courts because activists argued that it let men off the hook and did not force a change in their (violent) behaviour. The law means that denunciations of domestic violence made to the police can no longer be withdrawn except with special permission from a judge. Moreover, cases including physical vi- 
olence now carry automatic 3-month minimum mandatory sentences (Instituto Patricia Galvão, 2017). Mediation, therefore, no longer occurs at police stations and cases are now heard in special courts with judges trained in gender issues and domestic violence, although there is a serious lack both in gender training and specialised courts (ibid). At the Family Alliance, staff said they were concerned by the punitive nature of the law and the lack of conversation around violent behaviour with the men themselves. Several staff argued that if women could be heard, then surely men could be heard too. Marina, a social worker, believed the Maria da Penha law was too punitive, without offering alternative spaces where men's violent behaviour could be discussed:

For men, the only thing is punishment and anything that punishes men, makes them angry. Nowadays, men go to court. Before the Maria da Penha Law, there was the cesta básica, there were some things....But now there's no questioning and talking about their behaviour, men go straight to prison. And even if there is the occasional help group for men, they have been sent there as a punishment. And nothing that has to do with punishment ever works. (Marina, Social Worker, April 15, 2015; personal communication)

Marina's comments seem to suggest a belief that mediation and the cesta básica were sometimes positive, and she views the growth in punitive charges towards men as negative. The staff felt ambivalent about the issue of going to the police, registering a complaint and the Maria da Penha law itself, because they believed that too much blame was then placed on men. Monica, the psychologist, also felt that women should monitor and question their own behaviour:

Going to the police is a complaint about his behaviour, but here, we make them question themselves. Who am I? How did I act? We ask questions so that they think about themselves too, the way they have acted. (Monica, Psychologist, March 5, 2015; personal communication)

Therefore, even though CDCMs are solely for women, the staff at the Family Alliance had taken it upon themselves to act as mediators of the violence because the staff disagreed with the punitive measures of the Maria da Penha law. Furthermore, it is interesting to note that at the Family Alliance, only $19 \%$ of women had filed a complaint to police, compared to $30 \%$ of service users in the feminist CDCM where research was also conducted. This suggests that women's right to report violence is not being consistently encouraged at the centre.

Mediation in centres aimed at helping women overcome their situation of domestic violence is controversial. In the feminist analysis of the unequal power relations between men and women in society, mediation is seen as unhelpful. Many feminist professionals believe that once the relationship has reached the level of physical violence, it is hard to rebuild. This is because fundamental aspects of autonomy such as bodily integrity, freedom of movement and the freedom to form interpersonal connections with people other than the batterer are more likely to be established outside of the battering relationship than within it (Westlund, 1999). As seen through Sandra's case, once her husband began drinking again, the cycle of abuse returned, which suggests that mediation had only worked temporarily and was not a strategy that helped end the violence she experienced. If anything, mediation without denunciation to the police could leave an abuser in a greater position of power, unconcerned that he would suffer legal and/or punitive outcomes for the violence.

Furthermore, during interviews and in general, daily conversations, all the staff stressed the importance of remembering the women's role in domestic violence. According to Margarida, a social worker: "women hit and women beat", and they often did not realise it. The staff also viewed the violence as inter-generational and explained that violent women were reproducing what they themselves had experienced in the home. "I get women here and their husbands say to me: 'She hits me. I don't know what to do with her, is there somewhere for me [to get help]?' I have to tell them that there isn't", said Margarida.

Female violence towards men is unfortunately very under-researched and results are conflicting: for example, Straus (2014) argues that there is a high rate of assault by women and that women are often the initiators of violence. Straus suggests that female violence needs to be addressed to improve the effectiveness of programs to prevent and stop VAW. However, others have rejected Straus' analysis of a form of "mutual combat" between couples, arguing that women's use of force against intimate male partners is usually resistive and self-defensive (Larance, 2017). Moreover, while violence against men is known to occur, statistics of male VAW are overwhelming and international organisations such as the UN have adopted the feminist argument that VAW is linked to patriarchy and women's unequal position in societies around the world (UN, 1993). Therefore, while female violence against men does exist and firmly needs more research, it does not appear to be a problem of equal weight compared to male VAW.

Finally, I also met several women who felt overwhelmed with their situation and on a number of occasions they arrived at the centre, saying they no longer felt capable of looking after the children. These women were suffering enormously: grinding poverty, difficulties with their children, and violence in the home as well as the high levels of urban violence surrounding them. However, for the staff at the Family Alliance, women rejecting their normative and biologically-linked role as mothers who loved and cared for their children was simply evidence of women no longer wanting to deal with their responsibilities. This is despite evidence that IPV carries 
a high cost to women's psychological and physical wellbeing, and includes physical symptoms and somatic complaints, as well as depression and post-traumatic stress disorder (PTSD; Foa, Cascardi, Zoellner, \& Feeny, 2000). Mothers were expected to love their children, linking into the Christian-based and cultural view of the mother as self-less and giving. Regardless of the structural hardships including poverty and urban violence, as well as high levels of machismo and control over women based on gendered norms, the staff at the Family Alliance did not accept these issues as reasons for not properly effecting their duties as mothers. Therefore, despite a surprising lack of conversation over the role that fathers could or should play and widespread male VAW, family unity was prioritised, regardless of the difficulties of living together.

It must, however, be noted that prioritising the family is consistent with the ethos of social work in Brazil. The family is considered the indispensable space for the survival and protection of the children and members of the family. According to the National Social Welfare Policy (Política Nacional de Assistência Social), the state sees the family as the link between the subjective (the individual) and the collective (society). As the mother has traditionally been seen as responsible for raising the children and taking care of the family, the woman therefore becomes the mediator between the state and the family or between the public and private realms. Therefore, both the state's and the FBO's focus on women is strongly matrifocal, placing an emphasis on motherhood and making women responsible for the family's well-being. Moreover, the state has a vested interest in women maintaining their role as primary carers, because it is related to the free labour and social cohesion that women and families provide.

\section{Conclusion}

This case study of an FBO as a provider of welfare services to battered women highlights that organisations with a conservative, gender-traditional basis can have negative impacts on an abused woman's ability to deal with violence. This occurs when patriarchal attitudes towards gender roles and relations are maintained, undermining women's ability to address the violence in their lives. As women's identity and subjectivity is mediated through their gendered, normative roles as wives, mothers and carers for the family, women are encouraged to accept mediation with their abuser, to forgive violent husbands and to question their own actions, for the 'good' of the family. The importance of the family appears to be consistent with the centre's Catholic foundation and faithbased values, despite the centre not using an overt religious perspective in services offered. This perspective influences the way in which gender and violence are understood and solutions proposed to address violence.

Mediation in the centre was a practice adopted to counteract the loss of mediation which had previously occurred in police stations and small claims courts. Therefore, women's rights upheld by the Maria da Penha law, which specifically sought to reduce mediation, are being undermined. Furthermore, a woman's right to live without violence is subordinated to a focus on family unity, in which so-called 'traditional' gender roles are supported, as are gender relations which uphold patriarchy and the importance of the male in the home. I also identified a strong focus on women's role as perpetrators of domestic violence. While under-researched, I have demonstrated that the weight given to this problem at the centre is inconsistent with international statistics which demonstrate that men are overwhelmingly the perpetrators IPV. The views on domestic violence identified in the centre appear to excuse and minimise male violence and even blame women for the violence they experience. Violence is viewed as a personal rather than collective or political issue, which depoliticises the rampant, world-wide problem of male VAW.

Therefore, the family focus within the Family Alliance and the subversion of women's rights upheld in the Maria da Penha law (due to the use of mediation; a lack of encouragement to denounce partners to the police and by not addressing VAW as a gender-based problem), points to a certain collusion between a patriarchal state and the Catholic Church, which is a relationship that has been naturalised and reinforced to different degrees since colonialism. While feminists have made great achievements in demanding that the state provide legal rights and advocacy services for abused women, these achievements appear to be simultaneously undermined when women's welfare services are provided by patriarchal, gender-conservative FBOs. Controversy over gender roles and relations is rife in Brazil and at the heart of it lies control over the perceived nature of women's roles in society.

\section{Acknowledgments}

I wish to thank the anonymous reviewers for their critical yet constructive feedback on earlier drafts of the manuscript. I would also like to thank the staff members and service users who generously shared their time and stories with me and who welcomed me into their organisations. Finally, I would like to thank the Centre for Research on Religion and Society (CRS) at Uppsala University for its support in the publication of this article.

\section{Conflict of Interests}

The author declares no conflict of interests.

\section{References}

Aune, K., \& Nyhagen, L. (2015). Religion, politics and gender. In J. Haynes (Ed.), Routledge handbook of religion and politics (2nd ed., pp. 1-33). New York, NY: Routledge. 
Bäckström, A., Davie, G., Edgardh, N., \& Petterson, P. (2010). Welfare and religion in 21st century Europe: Volume 1. Farnham: Ashgate.

Beckford, J. A. (2011). Religious diversity and social problems: The case of Britain. In T. Hjelm (Ed.), Religion and social problems (pp. 53-66). New York, NY: Routledge.

Biebricher, T. (2011). Faith-based initiatives and pastoral power. Economy and Society, 40(3), 399-420.

Boesten, J. (2014). Inequality, normative violence and livable life: Judith Butler and Peruvian reality. In P. Drinot (Ed.), Peru in theory (pp. 217-243). New York, NY: Palgrave.

Bradley, T. (2010). Religion as a bridge between theory and practice in work on violence against women in Rajasthan. Journal of Gender Studies, 19(4), 361-375.

Cerqueira, D., \& Coelho, D. S. C. (2014). Estupro no Brasil: Uma radiografia segundo os dados da saúde [Rape in Brazil: A radiography according to health data] (Preliminary Report no 11). Brasilia: IPEA.

Cerqueira, D., Coelho, D. S. C., \& Ferreira, H. (2017). Estupro no Brasil: Vítimas, autores, fatores situacionais e evolução das notificações no sistema de saúde entre 2011 e 2014 [Rape in Brazil: Victims, authors, situational factors and the evolution of notifications in the health system between 2011 and 2014]. Revista Brasileira Segurança Publica, 11(1), 24-48.

Chong, K. H. (2008). Deliverance and submission: Evangelical women and the negotiation of patriarchy in South Korea. Asian Journal of Social Science, 38(6), 716-737.

Dagnino, E. (2005). Meanings of citizenship in Latin America. IDS Working Paper 258. Brighton: Institute of Development Studies.

Dobash, R., \& Dobash, R. (1980). Violence against wives: A case against the patriarchy. London: Open Books.

Dore, E. (2000). One step forward, two steps back: Gender and the state in the long nineteenth century. In E. Dore \& M. Molyneux (Eds.), Hidden histories of gender and the state in Latin America (pp. 3-32). Durham, NC: Duke University Press.

Drogus, C. A. (1997). Women, religion, and social change in Brazil's popular church. Indiana, IL: University of Notre Dame Press.

Drogus, C. A., \& Stewart-Gambino, H. (2005). Activist faith: Grassroots women in democratic Brazil and Chile. University Park, PA: Pennsylvania State University Press.

Foa, E. B., Cascardi, M., Zoellner, L. A., \& Feeny, N. C. (2000). Psychological and environmental factors associated with partner violence. Trauma, Violence and Abuse, 1(1), 67-91.

Garcia, L. P., Freitas, L. R. S., Marques da Silva, G. D., \& Höfelmann, D. A. (2013). Violência contra a mulher: Feminicídios no Brasil [Violence against women: Femicides in Brazil]. Brasilia: IPEA. Retrieved from http://www.mpsp.mp.br
Garcia-Moreno, C., Jansen, H., Ellsberg, M., Heise, L., \& Watts, C. (2006). Prevalence of intimate partner violence: Findings from the WHO multi-country study on women's health and domestic violence. The Lancet, 368(9543), 1260-1269.

Ghatak, S., \& Abel, A. S. (2013). Power/faith: Governmentality, religion, and post-secular societies. International Journal of Politics, Culture and Society, 26, 217-235.

Giumbelli, E. (2008). A presença do religioso no espaço público: Modalidades no Brasil [The presence of religion in the public sphere]. Religião e Sociedade, 28(2), 80-100.

Goldstein, D. (2003). Laughter out of place: Race, class, violence and sexuality in a Rio shantytown. Berkeley, CA: University of California Press.

Haaken, J., Fussell, H., \& Mankowksi, E. (2007). Bringing the church to its knees: Evangelical Christianity, feminism, and domestic violence discourse. Psychotherapy and Politics International, 5(2), 103-115.

Hautzinger, S. (2007). Violence in the City of Women: Police and batterers in Bahia, Brazil. Berkeley, CA: University of California Press.

Hjelm, T. (2015). Introduction. In T. Hjelm (Ed.), Is God back? Reconsidering the new visibility of religion. London: Bloomsbury Press.

Htun, M. (2003). Sex and the state: Abortion, divorce, and the family under Latin American dictatorships and democracies. Cambridge: Cambridge University Press.

Instituto Patricia Galvão. (2017). Dossiê violência contra as mulheres [Violence against women dossier]. Agencia Patrícia Galvão. Retrieved from http://www. agenciapatriciagalvao.org.br

Jeffreys, S. (2011). Descularisation and sexual equality. British Journal of Politics and International Relations, 13, 364-382.

Larance, L. Y. (2017). A practitioner's response to: “Addressing violence by female partners is vital to prevent or stop violence against women: Evidence from the multisite batterer intervention evaluation", by M. Straus. Violence Against Women, 23(1), NP1-NP2.

Lewy, C. S., \& Dull, V. (2005). The response of Christian clergy to domestic violence: Help or hindrance? Aggression and Violent Behavior, 10(6), 647-659.

Macaulay, F. (2005). Judicialising and (de)criminalising domestic violence in Latin America. Social Policy \& Society, 5(1), 103-114.

Marcílio, M. L. (1993). Apresentação [Introduction]. In M. L. Marcílio (Ed), Família, mulher, sexualidade e igreja na história do Brasil [Family, women, sexuality and the church in the history of Brazil]. São Paulo: Edições Loyola.

Mariz, C. L. (1992). Religion and poverty in Brazil: A comparison of Catholic and Pentecostal communities. Sociological Analysis, 53, 63-70.

Mead, L. (2005). A summary of welfare reform. In L. Mead \& C. Beem (Eds.), Welfare reform and politi- 
cal theory (pp. 10-33). New York, NY: Russell Sage Foundation.

Merry, S. E. (2001). Rights, religion and community: Approaches to violence against women in the context of globalization. Law and Society Review, 35(1), 39-88.

Montero, P. (2012). Controvérsias religiosas e esfera pública [Religious controversies and the public sphere]. Religião e Sociedade, 32(1), 167-183.

Mourier, E. (2013). Religion as a social substitute for the state: Faith-based social action in twenty-first century Brazil. In G. Carbonnier (Ed.), International development policy, religion and development (pp. 79-94). Basingstoke: Palgrave MacMillan.

Myscofski, C. A. (2013). Amazon wives, nuns and witches: Women and the Catholic church in colonial Brazil 1500-1822. Austin, TX: University of Texas Press.

Nason-Clark, N. (1997). The battered wife: How Christians confront family violence. Louisville, KT: Westminster John Knox Press.

Orozco, Y. P. (2009). Violência, religião e direitos humanos [Violence, religion and human rights]. In Y. P. Orozco (Ed.), Religiões em diálogo: Violência contra as mulheres [Religion in dialogue: Violence against women] (pp. 131-140). Washington, DC: Catholics for Choice.

$\emptyset$ steb $\varnothing$, M. T., \& Haukanes, H., \& Blystad, A. (2013). Strong state policies on gender and aid: Threats and opportunities for Norwegian faith-based organisations. Forum for Development Studies, 40(2), 193-216.

Parker, R. (2009). Civil society, political mobilization, and the impact of HIV scale-up on health systems in Brazil. Journal of Acquired Immune Deficiency Syndromes, 52(1), 49-51.

Plesset, S. (2006). Sheltering women: Negotiating gender and violence in Northern Italy. Stanford, CA: Stanford University Press.

RHR, \& WHO. (2013). Global and regional estimates of violence against women: Prevalence and health effects of intimate partner violence and non-partner sexual violence. Geneva: Reproductive Health and Research \& World Health Organisation.
Rostas, S., \& Droogers, A. (1993). Introduction. In S. Rostas \& A. Droogers (Eds.), The popular use of popular religion in Latin America. Amsterdam: CEDLA Latin American Studies.

Sager, R. (2010). Faith, politics and power: The politics of faith-based initiatives. Oxford: Oxford University Press.

Sagot, M. (2013). El femicidio como necropolítica [Femicide as necropolitics]. Labrys. Retrieved from https://www.labrys.net.br/labrys24/feminicide/ monserat.htm

Scheper-Hughes, N. (1993). Death without weeping: The violence of everyday life in Brazil. Berkeley, CA: University of California Press.

Secretaria de Transparência \& DataSenado. (2013). Violência doméstica e familiar contra a mulher [Domestic and family violence against women]. Brasilia: Senado Federal.

Stoll, D. (1990). Is Latin America turning Protestant? The politics of evangelical growth. Berkeley, CA: University of California Press.

Straus, M. (2014). Addressing violence by female partners is vital to prevent or stop violence against women: Evidence from the multisite batterer intervention evaluation. Violence Against Women, 20(7), 889-899.

United Nations. (1993). Declaration on the elimination of violence against women. New York, NY: United Nations. Retrieved from www.un.org

Vilhena, V. C. (2011). Uma igreja sem voz: Análise de gênero da violência doméstica entre mulheres evangélicas [A church without a voice: A gender analysis of domestic violence among evangelical women]. São Paulo: Fonte Editorial.

Waiselfisz, J. J. (2015). Mapa da violencia 2015: Homícidio de mulheres no Brasil [Violence map 2015: Female homicides in Brazil]. Brasilia: Flacso Brasil. Retrieved from www.mapadaviolencia.org.br

Westlund, A. (1999). Pre-modern and modern power: Foucault and the case of domestic violence. Signs, 24(4), 1045-1066.

\section{About the Author}

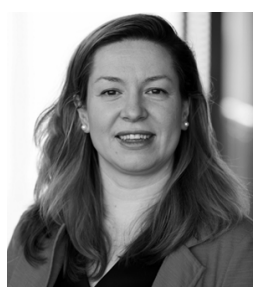

Kim Beecheno (Dr) is currently Guest Researcher at the Centre for Research on Religion and Society (CRS) at Uppsala University, Sweden. She obtained her PhD in Sociology of Religion at King's College London in 2018 with her thesis Faith and Feminism: Religion, Rights and Violence Against Women in Brazil. Her work focuses on intersections between religion, gender and violence, with particular attention to Latin America. 